\title{
Judicial Review Implementation On Dissenters Notary Rights In Making Deeds
}

\begin{abstract}
Binta Istiqlaly ${ }^{1}$ and Umar Ma'ruf ${ }^{2}$
Abstract. The purpose of this study was to: 1) Knowing and analyzing on the Implementation of the Right Dissenters in the Making Notary Deed. 2) To determine and analyze about the obstacle Notaries in Implementing Dissenters rights. The method used in this research is the empirical jurisdiction. Adopting legislation, learning materials primary and secondary law. The technique of collecting data using interviews and literature study and data analysis techniques qualitative analysis using descriptive analysis decomposition.

After doing research Juridical Review of Implementation of the Right Dissenters In the Manufacture Notary Deed to a conclusion that is Implementation of the Dissenters rights in the Making Notary Deed is basically the right to withdraw from testifying upfront Court in Civil and Criminal problem. Implementation of the right of refusal notaries in practice, if it turns out the notary as a witness or a suspect, defendant, or in the examination by the Board of Trustees Notary divulge and provide information/statements should shall be kept confidential, while legislation is not ordered, then the complaint filed by parties who feel aggrieved can sue the notary.

As well as Obstacles Notaries in options or Use Dissenters rights in the Making Deed is faced by a notary public in using the right of refusal which are the Assembly, Regional Supervisor (MPD) approved the request of the police in the inspection of a notary public, a notary unable to escape to does not provide information because the police already have the recommendation of the Supervisory Council of Regions (MPD). Another constraint is that if the investigating authorities in this case the police use forceful measures with the reason for the interest of the investigation, the notary can not usually be avoided by reason of use right of refusal because the police could have used the excuse that the notary was not cooperative in providing information regarding the deed he made, so that the police do a forced effort.

Keywords: Dissenters Rights; Notary and Deed.
\end{abstract}

\section{Introduction}

"Indonesia is based on law (Rechtsstaat) is not based on power alone (Machsstaat)", Indonesia is a constitutional state based on Pancasila and the Constitution of the Republic of Indonesia of 1945.

The principle of the State of Law itself is a guarantee of certainty, order, and legal protection that core truth and justice. According Sudikno Mertokusumo, in law enforcement typically there are three elements that must be considered, namely the rule of law (rechtssicherheit), usefulness (zweckmassigkeit), and justice (gerechtigkeit). ${ }^{4}$

Certainty, order and protection of the law generally requires evidence clearly define the rights and obligations of a person as a subject of law in society.

\footnotetext{
${ }^{1}$ Master of Notary Law Students, Sultan Agung Islamic University in Semarang email Email: bintaistiqlaly045@gmail.com

${ }^{2}$ Faculty of Law UNISSULA

${ }^{3}$ General Explanation of the 1945 Constitution, on the System of the State Government, the number 1.

${ }^{4}$ Sudikno Mertokusumo and A. Pitlo, 1993, Bab-bab Tentang Penemuan Hukum, Citra Aditya Bakti, Yogyakarta, p.1.
} 
Society needs someone whose testimony is reliable, trustworthy, whose signature and seal guarantees and compelling evidence, an impartial and advisors without blemish (onkreukbaar or unimpeachable), shut up, and make a deal to protect on the coming days. $^{5}$

In this case the officer in question was a notary. It is then arranged and confirmed inNotary Act (hereinafter in brief UUJN), In Article 1 paragraph 1 of Notary law (UUJN) confirms that the notary is a public official authorized to make an authentic deed and have other powers as mentioned in this law or by other laws.

Notary in their profession to provide public services should behave according to the rules, this is important because the notary duties of office is not solely for personal interests, but also for the benefit of society, as well as an obligation to ensure the correctness of the deed he had done, because it is a notary demanded more sensitive, honest, fair, and transparent in the manufacture of an authentic deed. In implementing the Notary position task must cling to the Notary office code of ethics, because without it the dignity and professionalism will be lost and no longer has the confidence of the public. Notaries are also required to have high moral values, because with the high moral notary will not abuse the authority that belongs to him, so that Notaries will be able to keep dignity as an official public who provide services in accordance with applicable rules and do not damage the image of the Notary itself. ${ }^{6}$

Obligation to keep confidential everything connected by deed and letters other purposes stipulated in the Law on Notary (UUJN) as Lex Specialist, other than that in Article 170 of the Book of the Law of Criminal Law states: 1) "Those who work, dignity, dignity or position are obliged to keep secret can ask relieved of the obligation to give testimony, about the things entrusted to them." 2)" The judge determines whether or not any legitimate reason for the request. "

On implementation found that the notary in the running position, which is associated with a deed, which cause problems, requiring a notary called as a witness by the legal authorities in relation to related tasks and position such, it raises a problematic itself for a notary, on the one hand notary shall maintain the confidentiality of the deed he had done, on the one hand it acts as a witness by law enforcement.

Based on the above background, writer interested in conducting further research that will be manifested in a study entitled: "Judicial Review Implementation on Dissenters Notary Rights in Making Deeds".

The formulation of the problem as follows: 1 . How the Implementation of the Dissenters rights in the Making Notary Deed; 2. What are the Obstacles Notaries in options or Use Rights Deed Dissenters in the Making

\section{Research methods}

The method used in this research is the empirical jurisdiction. Adopting legislation, learning materials primary and secondary law. The technique of collecting data using interviews and literature study and data analysis techniques qualitative analysis using descriptive analysis decomposition.

\section{Results and Discussion}

\subsection{Implementation of Dissenters rights in the Making Notary Deed.}

Basically right of refusal is the right to withdraw from testifying upfront Court in Civil

\footnotetext{
5 Tan Thong Kie, 2011, Serba Serbi Praktek Notaris, Ichtiar Baru Van Hoeve, Jakarta, p. 449.

${ }^{6}$ Komar Andasasmita, 1981. Notaris Dengan Sejarah, Peranan, Tugas Kewajiban, Rahasia Jabatannya, Sumur, Bandung, p. 14.
} 
and Criminal problem. In civil cases, notaries more flexibility to use the right of refusal granted the law to him. ${ }^{7}$ The term right of refusal is a translation of the Dutch language verschoningsrecht which means it is exempt from the right to give testimony as a witness in a civil or criminal case. This right is an exception to the general principle that any person summoned as a witness is obliged to give that testimony. Dissenters rights can be found in Article 16 paragraph (1) e of Act No. 30 of 2004 jo Act No. 2 of 2014 Number of Notary Positions. This dissenter right in practice still puzzling notaries to use it. This is because the right of refusal is still implicated in practice, especially in criminal cases. In the criminal case material sought is the truth so that the presence of the Notary as witnesses is required, as opposed to civil lawsuits seeking formal correctness. The presence of a notary already be considered to exist with the presented notarial deed made by the notary ${ }^{8}$.

According to the Regulation of the Minister of Justice and Human Rights of the Republic of Indonesia, basically Notary Regional Supervisory Council has the authority to provide Attendance Permit Notaries In the Court of Justice does not contradict regulations and laws. The key task of the notary is to create an authentic deed. As for the authentic word according to Article 1870 of the Civil Code provides for the parties that make it a perfect proof. Therein lies the importance of a notary, that notary because Law is authorized to create a tool that is perfect evidence, in the sense that what is mentioned in an authentic deed was essentially considered to be true so long as no evidence to the contrary ${ }^{9}$, In Notary law (UUJN), duties and functions of the Notary as follows ${ }^{10}$ :

- Letters posted under hand by enrolling in a special book (waarmerking)

- Make a copy of the original copy of the letter under the hand form which contains a description as written and illustrated in the letter in question.

- Approve their compatibility with a copy of the original letter (legalized)

- Providing legal counseling in connection with a deed

- A deed relating to land.

- Creating a treatise deed auction

To correct clerical errors or typographical errors contained in the minutes of the signed deed, to make the minutes and notes that the original certificate specifying the date and number of the minutes of the correction, and a copy was given to the parties in accordance with Article 51 of the Notary law Act (UUJN),

\subsection{Implementing Constraints Dissenters Rights on Notary Deed Making}

In the completion of a criminal or civil case the presence of witnesses and the statements given by witnesses helped the settlement. Under Article 1 point 26 of the Criminal Code states that a witness is a person who can provide information for the purpose of investigation, prosecution and the judiciary about a criminal case that he heard him, he saw himself and his own experience. In carrying out their duties, a notary is protected by law, as a suspect though still given rights, moreover notary who

\footnotetext{
7 Interview with Sakti Harlambang, SH., M.Kn As a Notary in Pemalang On September 08, 2019 10:00 pm Februri.

8 Rita Permanasari , Akhmad Khisni, Imunitas Hukum Bagi Notaris Yang Membuka Rahasia Jabatan, Vol 5 No March 1, 2018

${ }^{9}$ Irawan Arief Firmansyah, Sri Endah Wahyuningsih, 2017, kewenangan majelis kehormatan notaris wilayah dalam memberikan persetujuan terhadap pemanggilan notaris oleh penegak hukum, Vol. 4 No. 3 September 2017

${ }^{10}$ Article 15 of Act No. 2 of 2014 amendments to the Act No. 30 of 2004 concerning Notary
} 
only act as a witness. With the institution Assembly of Trustees as contemplated in Notary law (UUJN), investigators will feel more facilitated to confiscate minutes of certificates and / or letters are placed in the minutes of the deed or protocol notary in storage notary, summoned a notary to be present in the examination relating to the deed that has been made with the approval of the Supervisory Council of Regions (hereinafter referred to as MPD) in accordance with the provisions of Article 66 of Law Position Notary (UUJN).

Likewise, if a witness refuses to sign the results of the examination, the investigator should not be forced, only need to note the reason does not want to sign the Minutes of Investigation (BAP) is. According to investigators, a notary witness only as one type of evidence, previously made efforts to obtain other evidence. As evidence in a criminal trial under Article 184 Criminal Procedure Code as follows: The testimony, Specification Expert, Letters, Petperformance, and Description defendant. ${ }^{11}$

If the examination of witnesses has been completed and investigators are still felt incomplete evidence tool, it can request expert witness testimony. The expert witness here include the statements of experts is evidence both in Article 184 Criminal Procedure Code. Stated in Article 186 Criminal Procedure Code that expert testimony is what an expert has stated in court. Expert witnesses are the opinions of experts related to science has been studied exhaustively and comprehensively about something what was requested consideration, such as a notary prompted consideration of a problem. ${ }^{12}$

There are several obstacles faced by a notary public in using the right of refusal which are the Assembly, Regional Supervisor (MPD) approved the request of the police in the inspection of a notary public, a notary public can not avoid to not provide information because the police already have the recommendation of the Council of Trustees regions (MPD).

Another constraint is that if the investigating authorities in this case the police use forceful measures with the reason for the interest of the investigation, the notary can not usually be avoided by reason of use right of refusal because the police could have used the excuse that the notary was not cooperative in providing information regarding the deed he made, so that the police do a forced effort. ${ }^{13}$

Right of refusal is das sollen or ideal conditions (should be). While his das sein is the reality of the conditions in which each side has a point of view of the corner of his own spectacles, such as police and judges who have the same interests want to find the truth materially. If no notice of exceptional provisions, actually a notary is prohibited notify quote, copy, and grosse deed to those who are not interested in the deed, including the police or judges.

A bad habit, if the notary had had suspicions about the truth of formal requirements penghadap, eg Identity Card (KTP) and a description he gave, but a notary keep the deed, then later the notary will have trouble when there is a dispute, where the notary will be asked to provide testimony.

The role of notaries in the judicial process, namely as witnesses and expert witnesses. If the notary acts as an expert witness, then it certainly will not be in violation of professional secrecy for information confined to a comprehensive knowledge and expertise and in-depth about the science of law and notaries. However, when a notary

11 Irawan Arief Firmansyah, Sri Endah Wahyuningsih, Peran Notaris Sebagai Saksi Dalam Proses Peradilan Pidana, Vol. 4 No. 3 September 2017

12 Ibid.

${ }^{13}$ Interview with Chaerul Achwan, SH. As a Notary in Pemalang On September 08, 2019 10:00 pm. 
acts as a witness, he will provide information regarding the substance of the deed, when there is an exceptional provision which requires a notary to testify. Witness testimony given in his capacity as an experienced or know of an event or the actual facts of an event that is being investigated. ${ }^{14}$

In civil judicial process is sought is the formal truth, that truth is only based on things that are presented as evidence by the parties in court, witness testimony is not the primary evidence. Things are given preference in civil court is evidence of the writing, especially writing in the form of an authentic deed. To call a notary as a witness in a civil case was not really necessary, is generally quite the deed alone as evidence. The witness testimony is required if there are parties who do not recognize the evidence of the piece, so it needs clarification neighbor where the written evidence. In civil judicial process evidence with the testimony can be done if there has been the beginning of proof by writing, after which the other evidence including the evidence of witness testimony. ${ }^{15}$

When a notary is required to give testimony upon request of the parties to classify evidence disputed article, generally notary will explain the formal procedures about how making a deed. As for the contents deed, notary only explain the purpose of the agreement or the legal acts. Notaries will explain that based on the testimony of the parties.

As with the criminal case in which the material is sought is the truth, the notary must be present to testify about what they have seen, known, and heard about an event so that the examination of the case so transparent. Based on the provisions set forth in Article 66 paragraph 1 of Notary law (UUJN) that for the benefit of a judicial process, investigators, prosecutors or judges with the approval of the Assembly Regional Supervisor (MPD) is authorized to call a notary to be present in the examination relating to the deed he made. Judge as one who lays down the law for prosecuting in one hand, while on the other hand the scope of knowledge of judges in the field of notaries is also limited, the necessary information from the notary about the validity, authenticity and validity of a deed made by the notary.

Notary office in carrying out a task is likely called as a witness in connection with a deed made. In this case a notary is always faced with a situation, which is to keep a secret office and provide limited testimony that he saw and he heard, either at the level of investigation and trial. When examined Article 4, paragraph 2 in conjunction with Article 16 paragraph 1 letter e in conjunction with Article 54 of Notary law (UUJN) is associated with the Article 66 UUJN, after obtaining permission from the Assembly Regional Supervisor (MPD), the notary can not refuse to be called to provide information regarding by deed made.

Notary simply act as a witness stating what is seen, known and heard of the case. The testimony of the notary with regard to the substance of the deed would not be considered a violation of the right of refusal notary Article 4, paragraph 2 in conjunction with Article 16 paragraph 1 letter e in conjunction with Article 54 of Notary law (UUJN), because the obligation to keep secret the job have been invalidated by acts criminal fraud.

Based on the explanation above, it can be explained that if a notary to witness in court, he still has the right of refusal. But if the notary as a suspect in the court, right of refusal was automatically disqualified. A noble professions like notaries requires professionalism and thoroughness. Glory of the profession can be kept intact and

\footnotetext{
${ }^{14}$ Arief Irawan Firmansyah, Op.Cit.

15 Ibid.
} 
awake when members of the profession to provide a positive contribution and do carelessness. ${ }^{16}$

\section{Closing}

\subsection{Conclusion}

Based on the research results can be concluded as follows:

- Implementation of the Dissenters rights in the Making Notary Deed is basically the right to withdraw from testifying upfront Court in Civil and Criminal problem. Implementation of the right of refusal notaries in practice, if it turns out the notary as a witness or a suspect, defendant, or in the examination by the Board of Trustees Notary divulge and provide information / statements should shall be kept confidential, while legislation is not ordered, then the complaint filed by parties who feel aggrieved can sue the notary.

- Obstacles Notaries in options or Use Dissenters rights in the Making Deed is faced by a notary public in using the right of refusal which are the Assembly, Regional Supervisor (MPD) approved the request of the police in the inspection of a notary public, a notary public can not avoid not provide information because the police already have the recommendation of the Supervisory Council of Regions (MPD). Another constraint is that if the investigating authorities in this case the police use forceful measures with the reason for the interest of the investigation, the notary can not usually be avoided by reason of use right of refusal because the police could have used the excuse that the notary was not cooperative in providing information regarding the deed he made, so that the police do a forced effort.

\subsection{Suggestion}

- In order to further optimize the notary in the case of maintaining the confidentiality deed by Notary law (UUJN).

- In order notary can also be more cooperative in providing information regarding the deed he had made to the investigating authorities for an interest in the investigation by the examination of a fair, transparent, and scientifically.

- In order to maintain the trust and to protect people who enlist the services of a Notary Public Notary called for more careful in carrying out his duties. For the authorities to make an authentic act is expected to always check every deed he made to avoid mistakes.

\section{Bibliography}

[1] Komar Andasasmita, 1981. Notaris Dengan Sejarah, Peranan, Tugas Kewajiban, Rahasia Jabatannya, Sumur, Bandung

[2] Sudikno Mertokusumo dan A. Pitlo, 1993, Bab-bab Tentang Penemuan Hukum, Citra Aditya Bakti, Yogyakarta.

[3] Soerjono Soekanto dan Soleman B. Taneko, 2001, Hukum Adat Indonesia, Raja Grafindo Persada, Jakarta.

[4] Tan Thong Kie, 2011, Serba Serbi Praktek Notaris, Ichtiar Baru Van Hoeve, Jakarta.

[5] Constitution Republic of Indonesia of 1945

[6] Act No. 2 of 2014 Amendment Act No. 30 of 2004 concerning Notary

\footnotetext{
${ }^{16}$ Interview with Sakti Harlambang, Op.Cit.
} 